\title{
SALARY DETERMINANTS OF ENTRY-LEVEL ACADEMIC ECONOMISTS AND THE CHARACTERISTICS OF THOSE HIRED ON THE TENURE TRACK
}

\author{
John P. Formby \\ University of Alabama \\ and \\ Gary A. Hoover \\ University of Alabama
}

\begin{abstract}
When examining salaries in labor markets, economists observe the characteristics of individual workers, employers, and jobs and seek to measure their impact on wages and salaries. In this paper we investigate and report on the determinants of salaries in the academic labor market for entry-level economists. Previous studies focusing on this market have explored the impact of gender and age on salaries [Formby et al., 1993; Barbezat, 1992; Raymond et al., 1988; McMillen and Singell, 1994]. The effects of academic reputation and departmental rankings of Ph.D. programs from which newly hired economists receive their degrees have also been investigated [Ehrenberg et al., 1998].

More recently, Siegfried and Stock [1999; 2001] provided a more extensive analysis of the labor market for entry-level economists by examining employment outcomes and salaries of a large sample of new Ph.D.s and whether they accepted jobs in academia, worked for a government agency, or went into the private sector. Their findings provide compelling evidence concerning variations in salaries across broad employment sectors. Our paper is more narrowly focused and reports on the results of a survey of the academic labor market for economists hired by four-year colleges and universities at the beginning of the 1998-99 academic year. The survey is similar in design to the one used by Formby et al. [1993], which reported results for the 198788 academic year. In our survey, an aggressive follow-up strategy resulted in a response rate of over 66 percent, which yields reliable information on the salaries and characteristics of economists hired into the academic labor market in 1998.

Many of the findings relating to the determinants of entry-level salaries are not surprising. The paper provides hard evidence concerning what many observers perceive as the way the entry-level market works. For example, it is not surprising that being hired into a tenure-track job results in a large and highly significant salary premium. However, we are able to provide information concerning the number of
\end{abstract}

Gary Hoover: University of Alabama, Box 870224, Tuscaloosa, AL 35487-0224. E-mail: ghoover@cba.ua.edu. 
economists hired into tenure-track and non-tenure-track positions and about other factors influencing salaries. Further, we show that the ranking of the department in which the newly hired economist did their Ph.D. work is highly correlated with the beginning salary and the quality of their job placement, as evidenced by the ranking of the hiring department. In addition, we provide evidence that indicates the market works quite differently depending upon whether the hiring department is ranked in terms of the research productivity of its faculty.

\section{THE SURVEY AND A BRIEF DISCUSSION OF CHANGES IN ENTRY- LEVEL HIRING ACROSS TIME}

Colleges and universities that were seeking to hire academic economists for the 1998-99 academic year were identified in two ways. First, we compiled a list of all academic institutions that advertised in the October or November 1997 issues of Job Openings for Economists (JOE). To this list we added all four-year colleges and universities that advertised open positions for economists in The Chronicle of Higher Education. An easy-to-complete survey form was mailed in mid-December 1998 to 675 potential employers. A total of 450 responses were received. Some responses were initially incomplete and extensive follow-up resulted in more completed survey forms. However, in a number of cases we were unsuccessful in securing missing data and these partial responses were not analyzed. Of the 450 complete responses, 42 did not include salary information. An additional 58 responses lacked necessary demographic information. The 179 respondents who noted that no new hires had been made at the entry level were also excluded. The remaining 207 surveys were used to construct a data set with completed responses. ${ }^{1}$ This sample is somewhat smaller than the similar survey of Formby et al. [1993], which had a usable sample of 268 observations for new hires in the 1987-1988 academic year.

Table 1 provides descriptive statistics. In the fall of 1998 the average salary of a newly hired academic economist was $\$ 51,842$, with a standard deviation of $\$ 10,664$. This compares to the fall 1987 mean salary (restated in 1998 dollars) of $\$ 45,258$ reported by Formby et al. [1993]. Thus, on average, real entry-level salaries rose by slightly less than 13 percent over the decade separating the surveys. Several other summary statistics of general interest warrant mention. Table 1 reveals that 143 (69.1 percent) of the entry-level economists hired in the fall of 1998 were men whose salaries averaged $\$ 52,148$. Women made up 30.9 percent of the sample with salaries averaging $\$ 50,980$. Thus the nominal salaries of women averaged 97.8 percent of comparable salaries of men. A decade earlier women accounted for 21.3 percent of new hires and their nominal salaries averaged 96.7 percent of men's salaries. Thus, it appears that gender-related average salaries have changed little across time ${ }^{2}$ but the number of women economists, as a share of all entry-level academic economists, has increased.

Two other differences in salaries in Table 1 are quite striking and are briefly discussed here. First, the salary differentials among economists hired into ranked and unranked departments appear to have expanded across time. Before summarizing specific findings with respect to departmental ranking, we briefly outline the logic 
TABLE 1

Sample Sizes and Summary Statistics for Selected Variables

\begin{tabular}{lrrr}
\hline & $\mathbf{N}$ & Mean & Standard Deviation \\
\hline Total & 207 & $\$ 51,842$ & 10,664 \\
Male & 143 & $\$ 52,148$ & 10,988 \\
Female & 64 & $\$ 50,980$ & 9,949 \\
Ph.D. & 181 & $\$ 52,941$ & 9,923 \\
A.B.D. & 26 & $\$ 43,752$ & 12,325 \\
Tenure Track & 161 & $\$ 54,344$ & 9,732 \\
Non-Tenure Track & 46 & $\$ 42,836$ & 8,880 \\
Published & 128 & $\$ 52,579$ & 10,524 \\
Not Published & 79 & $\$ 50,502$ & 10,840 \\
& & & \\
Hiring School & & & \\
Ranked & 132 & $\$ 55,870$ & 9,335 \\
Unranked & 75 & $\$ 44,600$ & 8,967 \\
Ranked-Top 50 & 40 & $\$ 61,038$ & 10,280 \\
Unranked and below 50 & 167 & $\$ 49,571$ & 9,530 \\
Business & 63 & $\$ 52,957$ & 11,652 \\
Non-business & 144 & $\$ 51,275$ & 10,207 \\
Private & 83 & $\$ 51,283$ & 11,111 \\
Public & 124 & $\$ 52,124$ & 10,392 \\
Ranked/Tenure & 111 & $\$ 57,836$ & 8,509 \\
Ranked/Non-tenure & 21 & $\$ 45,476$ & 6,141 \\
Unranked/Tenure & 49 & $\$ 46,717$ & 7,628 \\
Unranked/Non-tenure & 25 & $\$ 40,617$ & 10,257 \\
& & & \\
Graduate Institution of Person & Hired & & \\
Private & 69 & $\$ 54,294$ & 9367 \\
Public & 138 & $\$ 50,532$ & 11082 \\
\hline & & &
\end{tabular}

of considering rankings and describe the ranking criterion. The rank of a department may be a proxy for the quality of the training economists receive as graduate students. Further, hiring departments may use the rank of the Ph.D. producing department as a signal of the quality and expected future productivity of the newly hired economist. Hiring departments that want to maintain or move up in the rankings have to compete for talent and may be willing to pay a premium to insure that they hire the most promising candidates. In Formby et al. [1993] the ranking of departments came from Hirsch et al. [1984]. We use a similar but more recent ranking by Scott and Mitias [1996] in which 240 departments are ranked based on the total number of published pages in selected journals by their faculty from 1984 through 1993 . The number of published pages, of course, is only one dimension of the quality of a department. At best, it measures the research productivity of the faculty. Nevertheless, research productivity is a much-discussed attribute of quality, and we have a systematic measure of the variable for a large number of colleges and universities in our sample. Departments that did not make it into Scott and Mitias' [1996] research productivity rankings are referred to as "unranked". 
Table 1 reveals that average salaries in hiring departments that were ranked in terms of scholarly research productivity were 25 percent higher, in 1998, compared to unranked departments. A decade earlier the differentials were somewhat smaller, but still a sizable 17 percent. While the salary differential between ranked and unranked departments widened across time, the proportion of new hires accepting entry-level academic jobs in ranked departments was approximately the same in 1998 as in 1987 (34.7 vs. 36.2 percent).

A second noteworthy difference in Table 1 is the salaries of economists hired into jobs that are on and off the tenure track. In some academic disciplines, notably in the humanities, a growing proportion of the faculty are in jobs that can never lead to tenure. The existence and growth of non-tenure-track jobs are widely perceived as a serious problem within some segments of the academic community. One of the objectives of the paper is to establish some basic data concerning non-tenure-track jobs in the entry-level market for economists. Table 1 reveals that 46 of the 207 (22.3 percent) newly hired economists did not receive tenure-track jobs in 1998-99. Further, the salary differences associated with the tenure track are striking. Economists hired in tenure-track jobs received an average salary of $\$ 54,344$. In contrast, the salaries of economists hired in non-tenure-track jobs averaged $\$ 42,836$. Thus, the nominal difference in average salaries suggests a premium of over 21 percent. Unfortunately, whether the proportion of economics positions filled by hiring on and off the tenure track has increased across time cannot be addressed because earlier surveys were not designed to address this issue. ${ }^{3}$

\section{THE EARNINGS EQUATION AND DATA}

The literature from labor economics suggests that the proper form for estimating an earnings equation for entry-level economists is:

$$
\operatorname{Ln} E_{i}=a+\Sigma b_{j} X_{j i}+U_{i}
$$

where $E_{i}$ denotes the salary of the $i$ th entry-level economist, $X_{j}$ refers to a vector of earnings determinants, $b_{j}$ represents the parameters to be estimated, and $U_{i}$ is an error term with a zero mean and constant variance.

The explanatory variables used in estimating the earnings equation are shown in Table 2. The meanings of most of the variables are clear and require little comment, but others are not as clear and we briefly discuss them here. The first set of variables in Table 2 relate to characteristics of the departments hiring an entry-level economist or characteristics of the department at which the new hire studied for the Ph.D. degree. The $H$-productivity variable measures the number of pages published from 1984 through 1993 by the faculty in the school that hired the new entry-level economist. The $P$-productivity variable measures the number of pages published over the same period by the faculty in the department in which the new hire did her or his Ph.D. work. As discussed above, these productivity variables are sometimes interpreted as proxies for the quality of departments hiring and producing economists in the entrylevel market for economists. 
The $C O L$ index requires some explanation. We used the Cost of Living calculator found on the website of $w w w$.homefair.com. This website provides a measure of the change in the cost of living, holding income constant, for a person who moves from one city to another in the fall of 1998. For our purposes we chose a city (Orlando, FL) with an index value of 100 as the base. We then normalized the cost of living in all other areas relative to that in Orlando, which is set to 100 . The homefair.com costs of living indices are constructed based upon procedures prescribed by the U.S. Bureau of Labor Statistics and are similar to the American Chamber of Commerce Research Association (ACCRA) COL measures, which are available for a limited number of urban areas. ${ }^{4}$

Highest Degree and Business School are categorical variables indicating whether the hiring department offers a Ph.D. degree and whether it is administratively located in a business school. Hires is also a categorical variable that indicates whether the hiring department employed two or more new entry-level economists rather than one. In Formby et al. [1993] this variable was found to be statistically significant and we include it in our model to see if this variable continues to be significant a decade later.

The second set of variables in Table 2 relates to the personal characteristics of individual entry-level economists hired into academic positions in the fall of 1998 . The Ph.D. variable indicates whether the newly hired economist had a completed degree when she or he started working. The Gender variable is another categorical variable, which is coded 1 for males.

Variables 1-10 were analyzed by Formby et al. [1993] in their study of the determinants of entry-level salaries of academic economists in 1987-1988. To these we add the variables numbered 11-14, all of which are categorical. The survey requested information on both race and country of national origin. Sample sizes were very small for African Americans, and for this reason we coded the data to create a variable indicating whether the new hire was a white non-Hispanic person ( $n=158)$ or "other" $(n=49)$, with the latter group including African Americans, persons of Hispanic origin, and Asians. The variable Published indicates whether the new hire had published a paper (or had a paper accepted for publication) at the time of initial appointment. Surprisingly, Table 1 reveals that more than 60 percent of all new hires were reported by their hiring department to have published at least one paper. It should be noted, however, that we did not ask about the quality of the publication. Tenure Track shows whether an individual was hired on the tenure track. As noted above, slightly more than 20 percent of the sample were hired into non-tenure-track jobs. Citizen / Green Card indicates whether the person hired was a U.S. citizen or held a green card. ${ }^{5}$

\section{THE DETERMINANTS OF ENTRY-LEVEL ACADEMIC SALARIES, 1998-99}

Table 3 reports estimates for two alternative models of entry-level academic salaries. Model 1 is shown in column 1 and is estimated using all observations. Model 2 reports separate estimates for ranked and unranked departments. Column 2 reports estimates for ranked departments and column 3 shows similar estimates for unranked departments. The question of which of these models provides the best explanation of 
TABLE 2

Definitions of Variables

\section{Characteristics of Hiring and Producing Departments}

1. H-Productivity

Productivity of the hiring department

2. P-Productivity

Productivity of the producing department

3. Ranked

Status of hiring department (ranked department $=1$, not ranked $=0$ )

4. Public

Major source of funding for the hiring departments' college or university (public = 1 , other $=0$ )

5. $\mathrm{COL}$

6. Highest Degree

Cost of living for the geographical area where the hiring department is located

7. Business School Highest degree offered by the hiring department $(\mathrm{Ph} . \mathrm{D}=1$, other $=0)$

8. Hires The administrative location of the hiring department (business school $=1$, other $=0$ ) Number of entry-level economists hired by the hiring department (multiple hires $=1$, single hire $=0$ )

\section{Characteristics of the Individual Entry Level Economist}

9. Ph.D.

10. Gender

11. Race

12. Published

13. Tenure Track

14. Citizen/Green Card Citizenship or green card status of the New hire (U.S. citizen or green card =1, other $=0$ )

Dependent Variable

15. Salary

Degree status at the time the survey was completed (Ph.D. = 1, A.B.D.=0)

Gender of new hire (male $=1$, female $=0$ )

Race and ethnicity of the new hire [white (non-Hispanic) $=1$, other $=0$ ]

Publication record at the time the survey was completed (published $=1$, no publications $=0$ )

Hiring status (tenure track $=1$, other $=0$ )

Academic year salary of the new hire without summer bonuses or other compensation

entry-level salaries is addressed by applying a Chow test, which is briefly explained below. But first, we provide further discussion of some of the variables and highlight general findings that emerge from both models.

The rankings of Scott and Mitias [1996] reveal that the lowest-ranked department published only 33.7 pages over a nine-year span, for an average 3.74 pages per year. We therefore coded all unranked departments as having a productivity measure of zero.

For ranked departments, an insignificant positive coefficient on $H$-productivity would seem problematic. Ehrenberg et al. [1998] shows, among other things, that more productive (higher-ranked) departments pay higher salaries to new hires. Further investigation reveals that the salary premium paid by higher-ranked departments is actually a result of the training that the new hire received.

The positive and significant sign on P-productivity in Model 1 reveals that every 100 published pages by the producing department carries a salary premium of 1.92 percent over the sample period. ${ }^{6}$ Higher-ranked departments hired persons from higher-ranked departments and consequently paid a salary premium for them. No person hired in the top 10 departments received their degree from a department ranked lower than 10, suggesting that higher-ranked schools seek out persons from their own ranks. Because elite programs only hire top-ranked persons, it may appear that these programs pay a premium.

Comparing the effects of the variables across the estimates in the two models yields some interesting findings. In the discussion that follows we employ a difference 
TABLE 3

Determinants of Academic Salaries of Entry-Level Economists

\begin{tabular}{|c|c|c|c|}
\hline & \multirow{2}{*}{$\begin{array}{c}\text { Model } 1 \\
\text { Entire } \\
\text { Survey }\end{array}$} & \multicolumn{2}{|c|}{ Model 2} \\
\hline & & $\begin{array}{c}\text { Ranked } \\
\text { Departments }\end{array}$ & $\begin{array}{c}\text { Unranked } \\
\text { Departments }\end{array}$ \\
\hline Intercept & $\begin{array}{l}10.3460^{\mathrm{a}} \\
(0.000)\end{array}$ & $\begin{array}{l}10.4514^{\mathrm{a}} \\
(0.000)\end{array}$ & $\begin{array}{l}10.3542^{\mathrm{a}} \\
(0.000)\end{array}$ \\
\hline $\mathrm{H}$-Productivity & $\begin{array}{l}0.1433 \times 10^{-4} \\
(0.2370)\end{array}$ & $\begin{array}{l}1.16 \times 10^{-5} \\
(0.267)\end{array}$ & - \\
\hline Public & $\begin{array}{c}0.0048 \\
(0.8555)\end{array}$ & $\begin{array}{l}0.0206 \\
(0.466)\end{array}$ & $\begin{array}{c}0.0294 \\
(0.579)\end{array}$ \\
\hline$C O L$ & $\begin{array}{c}0.0010 \\
(0.1520)\end{array}$ & $\begin{array}{c}0.0010 \\
(0.137)\end{array}$ & $\begin{array}{c}0.0004 \\
(0.831)\end{array}$ \\
\hline Highest Degree & $\begin{array}{r}0.0914^{\mathrm{a}} \\
(0.0034)\end{array}$ & $\begin{array}{c}0.0418 \\
(0.196)\end{array}$ & $\begin{array}{l}0.0305 \\
(0.755)\end{array}$ \\
\hline Business School & $\begin{array}{r}0.0670^{\mathrm{b}} \\
(0.0158)\end{array}$ & $\begin{array}{l}0.0515^{\mathrm{c}} \\
(0.084)\end{array}$ & $\begin{array}{c}0.0756 \\
(0.183)\end{array}$ \\
\hline Ph.D. & $\begin{array}{r}0.0703^{\mathrm{c}} \\
(0.0823)\end{array}$ & $\begin{array}{c}0.0773 \\
(0.121)\end{array}$ & $\begin{array}{c}0.0617 \\
(0.380)\end{array}$ \\
\hline Race & $\begin{array}{c}0.0177 \\
(0.5765)\end{array}$ & $\begin{array}{c}-0.0053 \\
(0.857)\end{array}$ & $\begin{array}{l}0.1477^{\mathrm{c}} \\
(0.074)\end{array}$ \\
\hline Gender & $\begin{array}{c}-0.0031 \\
(0.9051)\end{array}$ & $\begin{array}{c}0.0257 \\
(0.352)\end{array}$ & $\begin{array}{c}-0.0353 \\
(0.496)\end{array}$ \\
\hline Tenure Track & $\begin{array}{l}0.1510^{\mathrm{a}} \\
(0.000)\end{array}$ & $\begin{array}{r}0.176^{\mathrm{a}} \\
(0.000)\end{array}$ & $\begin{array}{l}0.1404^{b} \\
(0.025)\end{array}$ \\
\hline Published & $\begin{array}{c}0.0275 \\
(0.2937)\end{array}$ & $\begin{array}{c}0.0172 \\
(0.517)\end{array}$ & $\begin{array}{c}0.0286 \\
(0.601)\end{array}$ \\
\hline P-Productivity & $\begin{array}{l}1.92 \times 10^{3} \mathrm{a} \\
(0.0095)\end{array}$ & $\begin{array}{l}1.32 \times 10^{-5 \mathrm{c}} \\
(0.076)\end{array}$ & $\begin{array}{l}2.00 \times 10^{-5} \\
(0.211)\end{array}$ \\
\hline Citizen / Green Card & $\begin{array}{r}0.0500^{\mathrm{c}} \\
(0.0988)\end{array}$ & $\begin{array}{l}0.0198 \\
(0.487)\end{array}$ & $\begin{array}{c}0.1180 \\
(0.131)\end{array}$ \\
\hline New Hires & $\begin{array}{r}0.0518^{\mathrm{b}} \\
(0.0380)\end{array}$ & $\begin{array}{c}0.0233 \\
(0.389)\end{array}$ & $\begin{array}{l}0.0985^{\mathrm{c}} \\
(0.061)\end{array}$ \\
\hline Adjusted $R^{2}$ & 0.4059 & 0.3555 & 0.1327 \\
\hline Number of Obs. & 207 & 132 & 75 \\
\hline
\end{tabular}

$\mathrm{P}$-values are given in parentheses.

a. significant at the 1 percent level

b. significant at the 5 percent level

c. significant at the 10 percent level

of differences technique, which allows us to make positive statements about the significance of variables in the estimates reported in Table 3.

Table 3 indicates that whether the hiring department is in a public or private university has no significant effect on the salary of the new hire once other determinants of entry-level salaries are taken into account. Three other variables-COL, Gender, and Published-have no significant effect in either Model 1 or 2. The fact that $C O L$ is not significant is mildly surprising. The obvious explanation for this is that departments that are located in areas with higher costs of living also offer compensating amenities that offset these costs. This is consistent with a literature that 
documents amenities that enhance the quality of life in higher-cost urban areas [Roback 1982; 1988; Blomquist, Berger, and Hoehn, 1988]. Nevertheless, these compensating amenities may not fully offset differences in costs of living, and our expectations were that COL would be positive and significant [DuMond et al. 1999].

Gender had a negative coefficient (being male had a negative impact on wages), but consistent with Formby et al. [1993] the coefficient is insignificant. The fact that Published was insignificant is not all that surprising given the possible range in publication quality.

Consistent with the results of a decade earlier, we find that being hired into a business school has a significant and positive effect on salaries in Model 1 and for persons hired into ranked departments in Model 2. In unranked departments, being hired into a department within a business school has no significant impact on salary.

The results for Race differ in Models 1 and 2. Recall that Race is a categorical variable that measures whether the hiring department reports that the new hire is white (non-Hispanic) or some other race. For unranked departments the results for Model 2 show a premium for white (non-Hispanic) entry-level economists in 1998-99. However, for ranked departments and in Model 1 Race is not significant. This suggests that Race influences entry-level salaries quite differently in ranked and unranked departments. The data show that only 12 percent of unranked departments hired nonwhite persons while in ranked departments the percentage was a little over 30 percent.

Some departments hired more than one entry-level economist in 1998-99. For example, one responding department reported hiring six entry-level faculty in one year. The fact that some departments were filling multiple positions led us to investigate whether a search for several economists might impact the salaries of the new hires. For the entire survey (Model 1), this variable was positive and significant, a result that parallels the findings of Formby et al. [1993].

The analysis reveals that the most interesting contributor to entry-level salaries is whether the new hire is on the tenure track. Table 3 reveals that Tenure Track is the only variable that is positive and significant in each of the earnings equations estimated for Model 1 and 2. Being hired on the tenure track adds approximately 19 percent to the salary of a new hire in a ranked department and slightly more than 15 percent to a new hire in an unranked department. For the overall survey, being hired on the tenure track added a 16 percent premium. ${ }^{7}$

It is often of interest to test for structural stability in an overall regression equation such as Model 1. In Model 1 we assume that all of the usual regression ordinaryleast squares assumptions apply throughout the entire sample. When applied to check for structural stability, an $F$-test, sometimes referred to as a Chow test, is a straightforward way of testing whether some of the estimated coefficients in the overall model differ for a subset of the data. We used Chow tests to investigate whether some structural differences existed in Model 1. Results from the Chow tests are reported in Table 4. We find significant structural differences in the sample when the data are separated into ranked and unranked departments. In particular, the Chow tests for Business School and Tenure Track are significant, indicating that structural differences exist. Thus, the two equations in Model 2 provide an improved estimate compared to Model 1. As a practical matter this means that the market for entry-level 
economists works differently depending upon whether ranked or unranked departments are hiring. This finding parallels an analogous result in Formby et al. [1993].

\section{CHARACTERTISTICS OF THOSE HIRED ON THE TENURE TRACK}

Tenure-track status is the only variable that is significant in all specifications and it is clearly a powerful determinant for the entire survey across all departments, ranked as well as unranked. The survey provides information that allows us to examine the characteristics of those hired on the tenure track relative to those hired into non-tenure-track positions. We use a Probit analysis to distinguish the significant characteristics of those persons who were hired on the tenure track from those that were not. Since Tenure Track is a categorical variable that has 0 and 1 values, a Probit model is an appropriate method for investigating this issue. In specifying the Probit model we note that several of the variables are specific to the individual. For example Race, Gender, Published, Citizen /Green Card, and Ph.D. are clearly individual specific. In addition, we interpret $P$-Productivity as indirectly reflecting the potential productivity of the new hire. The logic of this is straightforward: ceteris paribus, a department with a highly productive research faculty is expected to produce Ph.D. students that are well trained and productive themselves. The other variables in Table 5 (H-Productivity, Public, Highest Degree, Business School, New Hires, and Ranked) all measure characteristics of the hiring department.

Table 5 reports the results of the Probit analysis. We find that three variables are highly significant. Accepting a position at a public institution (Public), completing all requirements for the Ph.D. degree (Ph.D.), and receiving graduate training in a department with a highly productive research faculty (P-Productivity) are all significant characteristics in attaining tenure-track positions.

The following discussion examines the magnitude of the influence that Public, Ph.D. and P-Productivity has in distinguishing between entry-level economists who are hired into tenure-track jobs and those accepting academic jobs that have no chance of tenure. To address this issue we use procedures outlined by [Greene 1993, 636-43]. The results are reported in Table 6 . To interpret Table 6 requires a brief discussion of the characteristics of the baseline measure we construct and use in gauging the impacts of the variables on the probability of being hired on the tenure track. The characteristics of the "representative" or "average" new hire are used in constructing the baseline. Compared to an average new hire (the baseline), how do individual-specific and hiring department-specific variables influence the probability of being hired on and off the tenure track?

The characteristics of the average or baseline new hire are as follows. As stated previously, the productivity measures used in Scott and Mitias [1996] are based on the number of pages published in 36 academic journals from 1984 through 1993. For P-Productivity, the data reveal that the average research productivity of the producing department was 2,149 pages over the sample period, which corresponds to a rank of 22 out 240. For H-Productivity, the data also show that, on average, the new hire's job was in a department with a productivity level of 637 pages, which corresponds to a rank of 66 out of 240 . Thus, when ranked by productivity the average producing 
TABLE 4

Chow Tests

\begin{tabular}{lcccccc}
\hline & \multicolumn{2}{c}{ All Departments } & \multicolumn{2}{c}{ Ranked Departments } & \multicolumn{2}{c}{ Unranked Departments } \\
With & $\begin{array}{c}\text { Without } \\
\text { intercept }\end{array}$ & $\begin{array}{c}\text { With } \\
\text { intercept }\end{array}$ & $\begin{array}{c}\text { Without } \\
\text { intercept }\end{array}$ & $\begin{array}{c}\text { With } \\
\text { intercept }\end{array}$ & $\begin{array}{c}\text { Without } \\
\text { intercept } \\
\text { intercept }\end{array}$ \\
\hline Ranked & 2.174 & 6.140 & - & - & - & - \\
& $(0.012)$ & $(0.000)$ & & & & \\
Tenure & 3.049 & 3.369 & 2.172 & 2.862 & 1.573 & 2.042 \\
& $(0.000)$ & $(0.000)$ & $(0.015)$ & $(0.002)$ & $(0.129)$ & $(0.017)$ \\
Business & 2.578 & 2.017 & 1.656 & 1.700 & 1.891 & 2.900 \\
& $(0.003)$ & $(0.047)$ & $(0.081)$ & $(0.076)$ & $(0.062)$ & $(0.004)$ \\
\hline
\end{tabular}

$\mathrm{P}$-values are given in parentheses.

department stood 44 slots higher than the average hiring department in 1998-99. This result is consistent with Pieper and Willis' [1999] finding that economics faculty with positions in Ph.D.-granting departments received their training and Ph.D.'s from higher-ranked departments. Therefore, in constructing the baseline we use 2,149 for the productivity of the producing department and 637 for the hiring department. The data reveal that, on average, public institutions hired more entry-level economists. Further, the average new hire accepted a job in a department that did not offer a Ph.D. and was not administratively located in a business school. On average, the potential hire reported having completed all degree requirements and was a white (non-Hispanic) male. As noted earlier, 62 percent of the new hires in the survey had at least one publication. Moreover, most of the new hires were U.S. citizens or had green cards and most departments hired only one entry-level person in 1998-99.

Table 6 reveals that the baseline (average) new hire had an 82 percent probability of being a tenure-track hire. This is interesting in itself, but when any of the characteristics of the individual are changed (that is, as we depart from the baseline), the significance of that particular variable is more clearly revealed. We focus here only on the significant variables in the Probit model reported in Table 5. Ceteris paribus, if the new hire accepts a job at a private institution instead of a public institution the probability of being a tenure-track hire falls by approximately 5 percentage points. The most dramatic effect takes place if the new hire has not fulfilled all of her or his degree requirements, in which case the probability of being hired on the tenure track falls by 24.7 percentage points.

Table 6 reveals that the productivity of the producing department has a positive and systematic impact on the probability that an entry-level economist is hired into a tenure-track position. Ceteris paribus, if we assume that the new hire receives her or his training in the most productive department instead of the $22^{\text {nd }}$ ranked department, the probability of being hired on the tenure track increases by approximately 8 percentage points. Conversely, if the new hire receives their $\mathrm{Ph} . \mathrm{D}$. training in a de- 
TABLE 5

Probit Estimates of Being Hired on the Tenure Track

\begin{tabular}{lclc}
\hline Constant & -0.7406 & Gender & -0.3579 \\
& $(0.1312)$ & & $(0.1551)$ \\
H-Productivity & $0.2968 \times 10^{-3}$ & Race & -0.3081 \\
& $(0.2090)$ & & $(0.3275)$ \\
Public & $0.5075^{\mathrm{b}}$ & Published & 0.3452 \\
& $(0.0386)$ & & $(0.1581)$ \\
Highest Degree & 0.4417 & P-Productivity & $0.1507 \times 10^{-3} \mathrm{~b}$ \\
& $(0.1641)$ & & $(0.0358)$ \\
Business School & 0.3692 & Citizen/Green Card & -0.3357 \\
& $(0.1681)$ & & $(0.253)$ \\
Ph.D. & $1.2248^{\mathrm{a}}$ & Hires & -0.2265 \\
& $(0.0002)$ & & $(0.3488)$ \\
\hline
\end{tabular}

$\mathrm{P}$-values are given in parentheses.

a. significant at the 1 percent level

b. significant at the 5 percent level

c. significant at the 10 percent level

partment ranked below 22 , say $50^{\text {th }}$, the probability of receiving a tenure-track job declines by 3.0 percentage points compared to the baseline. Table 6 indicates receiving Ph.D. training in highly ranked departments (the elite among the top 10) has a sizable impact on getting a tenure-track job. However, economists trained in departments ranked from $20^{\text {th }}$ to $50^{\text {th }}$ experience only small decreases in tenure-track probabilities compared to the baseline.

\section{CONCLUSIONS}

This study uses survey data to investigate the determinants of entry-level salaries of academic economists in the 1998-99 academic year. Unlike previous studies of the labor market for economists we focus on tenure- and non-tenure-track jobs. We identify a number of important factors influencing the entry-level market for economists. In 1998-99 more than 20 percent of all new entry-level hires in economics accepted non-tenure earning positions and we find Tenure Track to be a large, significant and robust determinant of entry-level salaries.

We also find that the market works quite differently depending upon whether the hiring department is ranked in terms of the research productivity of its faculty. Chow tests reveal that estimating the determinants of salaries separately for ranked and unranked hiring departments results in improved understanding of the entry-level labor market in 1998-99. The variable Tenure Track is important in both market segments. In ranked departments, being hired on the tenure track adds more than 19 percent to the entry-level salary. In unranked departments the tenure-track premium is slightly more than 15 percent.

Business schools with ranked departments pay a premium, but those in unranked departments do not. Further, in ranked departments the productivity of the faculty in which the new hires did their Ph.D. work results in both higher salaries and im- 
TABLE 6

Probability of Being Hired on the Tenure Track

\begin{tabular}{lcc}
\hline & $\begin{array}{c}\text { Probability of Being } \\
\text { Hired on the Tenure Track }\end{array}$ & $\begin{array}{c}\text { Percent Changed } \\
\text { Compared to the Baseline }\end{array}$ \\
\hline Baseline & 82.0 & - \\
Private instead of Public & 77.3 & -4.7 \\
ABD instead of Ph.D. & 57.3 & -24.7 \\
& & \\
Productivity of the Producing Department & +8.3 \\
Highest Ranked & 90.3 & +3.4 \\
$10^{\text {th }}$ Ranked & 85.4 & -0.1 \\
$20^{\text {th }}$ Ranked & 81.9 & -1.5 \\
$30^{\text {th }}$ Ranked & 80.5 & -2.4 \\
$40^{\text {th }}$ Ranked & 79.6 & -3.0 \\
$50^{\text {th }}$ Ranked & 79.0 & \\
\hline
\end{tabular}

a. The Baseline is constructed using the average characteristics of the entire sample, which are as follows:

P-Productivity $=2149$ pages, which corresponds to a rank of 22 for the producing department,

$H$-Productivity $=637$ pages, which corresponds to a rank of 66 for the hiring department,

Public $=1$, the average new hire is employed by a public four-year college or university,

Ph.D. = 0, the average new hire is employed in a non-Ph.D. granting department,

Business $S$ chool $=0$, the average new hire's job is not in a business school,

Race $=1$, the average new hire is white and non-Hispanic,

Gender $=1$, the average new hire is male,

Published $=1$, the average new hire has published at least one paper,

Citizen / Green Card = 1, the average new hire is either a U.S. citizen or has a green card, and

Hires $=0$, the average new hire is in a department that employed only one entry-level economist in 19981999.

proved job placement in the sense that the new hires obtain positions with higherranked departments than would have been possible if they had done their Ph.D. work in lower ranked departments. The ranking of the department in which the new hires did Ph.D. work is not a significant determinant of salaries in the unranked segment of the market.

Compared to other studies of the academic market for economists, a novel feature of this paper is that it investigates the characteristics of individual economists and hiring departments that influence the probability of being hired into a tenure-track job. Three variables are shown to be highly significant in distinguishing those who were hired into tenure-track academic positions in economics from those accepting non-tenure-track jobs. Not surprisingly, we find that having completed all requirements for the Ph.D. degree is an extremely important determinant of the probability of acquiring a tenure-track job. We also find that accepting a position at a public rather than a private college or university significantly influences the probability that the job is on the tenure track. Finally, Ph.D. training in a highly productive department has a large and significant effect on the probability of receiving a tenuretrack position.

It is natural to explore the following question, which will be of interest to some readers: What guidance do our results provide for young would-be economists who 
think they may want to pursue an academic career and who are particularly concerned about the first job? Our results are consistent with the following advice. If young would-be economists are interested in an academic career with a high-paying first job that provides a chance for tenure, they should do their Ph.D. work at the most highly ranked (research productive) department possible. Further, they should complete their Ph.D. work in a timely manner. Finally, they should seriously think about pursuing an entry-level job in a department that is administratively located within a business school and within a public university.

We close by focusing on the following question: What are some of the factors of interest in the entry-level market that our study has failed to identify and uncover? The paper provides a number of interesting results that confirm casual impressions concerning how the entry-level market for academic economists works. But many other equally interesting questions are not addressed. First, we note that the quality of a department hinges not only on research productivity as in this paper, but also on teaching. Two equally ranked research departments may differ markedly in terms of teaching, which may be reflected in attrition rates of Ph.D. students.

Another issue not addressed, which could be important involves compensating wage differentials and trade-offs, both of which are almost always at work in labor markets. For example, we find that an entry-level economist in a department in a business school in ranked departments is paid a salary premium, but the classes the instructor must teach may be larger and the economics faculty in a business school may have to teach large numbers of students who have no interest in economics. The business school premium may in fact be a compensating differential for putting up with large numbers of uninterested students. Similarly, the newly hired economist has preferences, which may not be consistent with choices that maximize the entrylevel salary and getting a tenure-track appointment. For example, some of the new hires who accepted non-tenure-track appointments in 1998-99 may have received exactly what they were seeking-a temporary job.

The questions we have not addressed lead us to be cautious in offering guidance to young would-be economists. Nevertheless, we are confident in suggesting that they pursue the highest quality Ph.D. program consistent with their abilities, that they complete the Ph.D. degree and that entry-level, tenure-track jobs are more likely to be found in public colleges and universities.

\section{NOTES}

The authors wish to thank Samuel Addy, Paul Pecorino, James Peoples, and three anonymous referees for their helpful comments. Thanks are also expressed to seminar participants at the University of Tennessee at Chattanooga. Research assistance was provided by Kenneth D. Griffin and Kimberly Lawrence. This paper was supported by research assistance from the Center for Business and Economic Research at the University of Alabama.

1. A few responding institutions hired more than one entry-level economist. The sample size of 207 is the total number of new hires for which complete information was available.

2. Formby et al. [1993] found that after controlling for other factors influencing salaries, the gender differences in 1987-1988 are not significant. We find and report similar results below. 
3. A casual review of $J O E$ reveals that approximately 80 percent of the academic jobs listed were tenure-track positions, which indicates that in 1998-99, employers were able to find candidates with qualifications that suited the position.

4. ACCRA provides cost of living indices for a number of urban areas, but not for all of the areas in which the colleges and universities in our sample are located. We can construct COL measures for almost all of the areas in our sample using homefair.com. In a small number of cases where the hiring department was located in an area for which a homefair.com index could not be computed, the flexibility of homefair.com allowed us to select a nearby geographical area with a similar population size and use its COL as a proxy. For the limited set of observations for which both ACCRA and homefair.com COL measures are available, we found no statistically significant effect of the COL index. However, theoretically, a COL measure should logically be included in the econometric specification. Therefore, to maximize our sample size we use the homefair.com indices because this permits us to use all 207 observations.

5. We group economists with green cards with U.S. citizens because the number of green card holders is small and they have the same rights to employment as U.S. citizens.

6. P-productivity is also significant in the ranked equation of Model 2, but at the 10 percent level of significance $(\mathrm{p}$-value $=0.076) . P$-productivity is not significant in unranked equation of Model 2.

7. The conversion into percentage differentials is given by $\left(e^{\text {coefficient }}-1\right) \times 100$.

\section{REFERENCES}

Barbezat, D. The Market for New Ph.D. Economists. Journal of Economic Education, Summer 1992, 262-76.

Blomquist, G., Berger, M., and Hoehn, J. New Estimates of Quality of Life in Urban Areas. American Economic Review, March 1988, 89-107.

DuMond, M., Hirsch, B., and Macpherson, D. Wage Differentials Across Labor Markets and Workers: Does Cost of Living Matter? Economic Inquiry, October 1999, 577-98.

Ehrenberg, R., Pieper, P., and Willis, R. Do Economics Departments With Lower Tenure Probabilities Pay Higher Faculty Salaries? The Review of Economics and Statistics, November 1998, 503-12.

Formby, J., Gunther, W., and Sakano, R. Entry Level Salaries of Academic Economists: Does Gender or Age Matter? Economic Inquiry, January 1993, 128-38.

Greene, W. Econometric Analysis. Macmillan Publishing Company, 1993, 636-43.

Hirsch, B., Austin, R., Brooks, J., and Moore, J. Economics Department Rankings: Comment. American Economic Review, September 1984, 822-26.

McMillen, D. and Singell, L. Gender Differences in First Jobs for Economists. Southern Economic Journal, January 1994, 701-14.

Pieper, P. and Willis, R. The Doctoral Origins of Economics Faculty and the Education of New Economics Doctorates. Journal of Economic Education, Winter 1999, 80-88.

Raymond, R., Sensowitz, M., and Williams, D. Does Sex Still Matter? New Evidence from the 1980s. Economic Inquiry, January 1988, 43-58.

Roback, J. Wages, Rents, and the Quality of Life. Journal of Political Economy, December 1982, 1257-78. . Wages, Rents, and Amenities: Differences Among Workers and Regions. Economic Inquiry, January 1988, 23-41.

Scott, L. and Mitias, P. Trends in Rankings of Economics Departments in the U.S.: An Update. Economic Inquiry, April 1996, 378-400.

Siegfried, J. and Stock, W. The Labor Market for New Ph.D. Economists. Journal of Economic Perspectives, Summer 1999, 115-34.

. So You Want To Earn a Ph.D. in Economics: How Much Do You Think You'll Make? Economic Inquiry, April 2001, 320-25. 